\title{
КОМПОНЕНТЫ СОСТАВА МАССЫ ТЕЛА ВЫСОКОКВАЛИФИЦИРОВАННЫХ ГРЕБЦОВ НА КАНОЭ, ВЫСТУПАЮЩИХ НА РАЗЛИЧНЫХ ДИСТАНЦИЯХ
}

\author{
Владимир Давыдов ${ }^{1}$, Владимир Шантарович ${ }^{2}$, Дмитрий Пригодич ${ }^{1}$
}

\begin{abstract}
${ }^{1}$ Полесский государственный университет, Пинск, Республика Беларусь, davydov55@list.ru
${ }^{2}$ Национальная команда Республики Беларусь по гребле на байдарках и каноэ, Министерство спорта и туризма, Минск, Республика Беларусь
\end{abstract}

https://doi.org/10.29038/2220-7481-2019-02-105-111

\begin{abstract}
Аннотации
Aктуальность. Вопросы изучения состава тела интересовали людей так или иначе на всём протяжении человеческой истории. Как свидетельствуют археологические находки фигурок каменного века, предпосылки для развития научного подхода к изучению состава тела создаются уже в эти далёкие времена. Цель работы исследовать компоненты состава массы тела высококвалифицированных гребцов на каноэ и взаимосвязь данных измерений с результатами выступлений. Материалы и методы исследования. Всего обследовано 146 спортсменов, из них - 124 мужчины и 22 женщины. Для определения жировой, мышечной и костной масс использованы формулы Я. Матейки и Э. Г. Мартиросова. Результаты. При сопоставлении показателей выявлено, что группа МСМК и ЗМС имеет лучшие результаты, чем группа МС и КМС, как по показателям жировой и мышечной массы тела, так и по времени прохождения 200-метровой дистанции. Выявлены достоверно значимые различия $(\mathbf{p}<0,05)$. У женщин-байдарочниц в показателях процентного содержания мышечной массы в группе ЗМС и МСМК и группе МС и КМС различия достоверно значимы $(\mathrm{p}<0,05)$. Связь показателей мышечной массы со временем прохождения 200-метровой дистанции статистически достоверна, где коэффициент корреляции составил 3,42 при $\mathrm{r}<0,390$ для $5 \%$ уровня значимости. На 500 -метровой дистанции у мужчин по показателям жировой, мышечной, костной массы и времени прохождения соревновательной 500-метровой дистанции лучшие результаты имеют ЗМС и МСМК, чем каноисты из группы МС и КМС. Различия составляют в среднем, соответственно, $4,77 \%$ и 4,04 с. Данные различия статистически достоверны $(\mathrm{p}<0,05)$. На этой же дистанции у женщин-байдарочниц различия статистически достоверны в показателях относительной жировой и мышечной массы тела $(\mathrm{p}<0,05)$. В группе 3МС и МСМК, между спортивным результатов и костной массой тела спортсменок, где $\mathrm{r}=0,352$, взаимосвязь достоверна $(\mathrm{p}<0,05)$. На дистанции 1000 м спортсмены группы ЗМС и МСМК по всем показателям превосходят группу МС и КМС, однако различия не достоверны (р>0,05). Корреляционная связь показателей жировой массы тела со временем прохождения соревновательной дистанции статистически достоверна $(\mathrm{p}<0,05)$. Аналогичная тенденция и у мужчин, выступающих на дистанции 5000 м, где спортсмены группы ЗМС и МСМК по всем показателям превосходят группу МС и КМС, но различия не достоверны (p>0,05). Bbøodb. Выявлено, что группа МСМК и ЗМС у мужчин на дистанции 200 м по жировой и мышечной массе тела превосходит группу МС и КМС. Различия достоверно значимы $(\mathrm{p}<0,05)$. У женщин по показателям жировой и мышечной массы в группе ЗМС и МСМК и группе МС и КМС различия достоверно значимы (p<0,05). Отмечается, что на дистанции 500 м лучшими показателями обладают спортсмены группы МСМК и ЗМС как у мужчин, так и у женщин. По показателям жировой и мышечной массы у спортсменок исследуемых групп различия достоверно значимы ( $<0,05)$. На дистанции 1000 м наилучшими значениями обладают спортсмены группы МСМК и ЗМС, но значения статистически не достоверны. Выявлено, что группа МСМК и ЗМС у мужчин обладает лучшим результатом, чем группа МС и КМС, как по времени прохождения 5000-метровой дистанции, так и по показателям состава массы тела, однако различия не достоверны (p>0,05).
\end{abstract}

Ключевые слова: гребля, каноэ, жировая и мышечная масса, дистанция.

Володимир Давидов, Володимир Шантарович, Дмитро Пригодич. Компоненти складу маси тіла висококваліфікованих веслярів на каное, які виступають на різних дистанціях. Актуальність. Питання вивчення складу тіла цікавили людей так чи інакше впродовж історії людства. Як свідчать археологічні знахідки фігурок кам'яного віку, передумови для розвитку наукового підходу до вивчення складу тіла створювалися вже в ці далекі часи. Мета роботи - дослідити компоненти складу маси тіла висококваліфікованих веслярів на каное та взаємозв'язок даних вимірювань із результатами виступів. Матеріали й методи дослідження. Усього обстежено 146 спортсменів, із них - 124 чоловіки та 22 жінки. Для визначення жирової, м'язової й кісткової маси використано формули Я. Матейки і Є. Г. Мартіросова. Результати. При зіставленні показників виявлено, що група МСМК та ЗМС має кращі результати, ніж група МC і КМС, як за показниками жирової й м'язової маси тіла, так і за часом проходження 200-метрової дистанції. Виявлено достовірно значимі відмінності (p<0,05). У жінок-байдарочниць у 
показниках відсоткового вмісту м'язової маси в групі ЗМС і МСМК та групі МС і КМС відмінності достовірно значимі $(\mathrm{p}<0,05)$. Зв'язок показників м'язової маси з часом проходження 200-метрової дистанції статистично достовірний, де коефіцієнт кореляції становив 3,42, при $\mathrm{r}<0,390$ для 5 \% рівня значущості. На 500-метровій дистанції в чоловіків за показниками жирової, м'язової, кісткової маси й часу проходження змагальної 500-метрової дистанції кращі результати мають ЗМС і МСМК, ніж каноїсти з групи МС та КМС. Відмінності становлять у середньому, відповідно, 4,77 і 4,04 с. Ці відмінності статистично достовірні $(\mathrm{p}<0,05)$. На цій самій дистанції в жінокбайдарочниць відмінності статистично достовірні за показниками відносної жирової й м'язової маси тіла (p<0,05). У групі ЗМС і МСМК між спортивними результатами та кістковою масою тіла спортсменок, де $\mathrm{r}=0,352$, взаємозв'язок достовірний $(\mathrm{p}<0,05)$. На дистанції 1000 м спортсмени групи ЗМС і МСМК за всіма показниками перевершують групу МС та КМС, однак відмінності не достовірні (p>0,05). Кореляційний зв'язок показників жирової маси тіла 3 часом проходження дистанції змагання статистично достовірний $(\mathrm{p}<0,05)$. Аналогічна тенденція й у чоловіків, які виступають на дистанції 5000 м, де спортсмени групи ЗМС і МСМК за всіма показниками перевершують групу МС та КМС, але відмінності не достовірні (р>0,05). Висновки. Виявлено, що група МСМК і ЗМС чоловіків на дистанції 200 м за показниками жирової й м'язової маси тіла перевершуює групу МС і КМС. Відмінності достовірно значимі $(\mathrm{p}<0,05)$. У жінок за показниками жирової та м'язової маси в групі ЗМС і МСМК та групі МС і КМС відмінності достовірно значимі $(\mathrm{p}<0,05)$. Відзначаємо, що на дистанції 500 м кращими показниками володіють спортсмени групи МСМК і ЗМС як серед чоловіків, так і серед жінок. За показниками жирової й м'язової маси в спортсменок обстежуваних груп відмінності достовірно значимі $(\mathrm{p}<0,05)$. На дистанції 1000 м найкращими значеннями володіють спортсмени групи МСМК та ЗМС, але значення статистично не достовірні. Виявлено, що в групі МСМК і ЗМС чоловіків фіксуються кращі результати, ніж у групі МС і КМС як за часом проходження 5000-метрової дистанції, так і за показниками складу маси тіла, проте відмінності не достовірні (p>0,05).

Ключові слова: веслування, каное, жирова й м'язова маса, дистанція.

Vladimir Davydov, Vladimir Shantarovich, Dmitry Prigodich. Components of Body Weight Composition of Highly Skilled Oarsmen and Canoeing, Speakers at Different Distances. Topicality. The questions of studying the composition of the body interested people one way or another throughout human history. As evidenced by the archaeological finds of stone age figures, the prerequisites for the development of a scientific approach to the study of body composition are already in these distant times. The purpose of the work is to study the components of the body weight of highly skilled canoe rowers and the relationship of measurement data with the results of performances. Materials and Methods. A total of 146 athletes were examined, including 124 men and 22 women. To determine fat, muscle and bone masses have been used the formula Y. Ukraine and E. G. Martirosov. Results. When comparing the indicators, it was found that the group of MSMC and ZMS have better results than the group of MS and KMS, both in terms of body fat and muscle mass, and the time of the 200-meter distance. Significant differences were revealed $(\mathrm{p}<0,05)$. Women-videocnet in the indicators of the percentage of muscle mass in the group of ZMS and MSIC and the group of MS and MMR differences are significantly significant $(\mathrm{p}<0,05)$. The relationship of muscle mass parameters with the time of the 200-meter distance is statistically significant, where the correlation coefficient was 3,42, with $\mathrm{r}<0,390$ for $5 \%$ of the significance level. 500 meter distance from the men in terms of fat, muscle, bone mass and the transit time of a competitive 500-meter distance, the best results are VMT and MSIC than the canoeists from the group of MS and MMR. The differences are on average, respectively, of 4,77\% and 4,04 C. these differences were statistically significant $(\mathrm{p}<0,05)$. At the same distance in female kayakers differences are statistically significant in terms of relative fat and muscle mass $(\mathrm{p}<0,05)$. In the group of ZMS and MSMC, between sports results and bone mass of athletes, where $r=0,352$, the relationship is significant $(\mathrm{p}<0,05)$. At a distance of $1000 \mathrm{~m}$ athletes of the group of ZMS and MSMC on all indicators exceed the group of MS and KMS, but the differences are not reliable ( $>>0,05)$. The correlation between the body fat mass and the time of passing the competitive distance is statistically significant $(\mathrm{p}<0,05)$. A similar trend is in men, performing at a distance of $5000 \mathrm{~m}$, where athletes of the group of ZMS and MSMC in all indicators exceed the group of MS and KMS, but the differences are not significant ( $\mathrm{p}>0,05)$. Conclusions. It was revealed that a group of world-class athlete and PMN men at a distance of $200 \mathrm{~m}$ to fat and muscle mass of the body superior to the MS group and the CCM. The differences were significant $(\mathrm{p}<0,05)$. Women on indicators of fat and muscle mass in a group of ZMS and MSIC and the group of MS and MMR differences are significantly significant $(\mathrm{p}<0,05)$. It is noted that at a distance of $500 \mathrm{~m}$ the best indicators are athletes of the msmk group and ZMS, both in men and women. According to the parameters of fat and muscle mass in the athletes of the examined groups the differences were significantly significant $(\mathrm{p}<0,05)$. At a distance of $1000 \mathrm{~m}$ the best values have athletes group msmk and ZMS, but the values are not statistically reliable. It was found that the group of MSMC and ZMS in men has a better result than the group of MS AND KMS, both in the time of passage of the 5000 -meter distance, and in terms of body weight, but the differences are not significant ( $>0,05)$.

Key words: rowing, canoe, fat and muscle mass, distance.

Введение. Определение состава тела имеет важное значение в спорте и используется тренерами и спортивными врачами при отборе и для оптимизации тренировочного режима в процессе подготовки к соревнованиям. Исследования состава массы тела человека приобретают в последние годы всё возрастающее значение [3; 4].

Результаты некоторых работ [1; 2] свидетельствуют, что состав тела имеет существенную взаимосвязь с показателями физической работоспособности человека с его адаптацией к условиям внешней 
среды, а также с профессиональной и спортивной деятельностью. В клинической, оздоровительной и спортивной медицине важное значение имеют задачи мониторинга состава тела. Сфера применения и возможности методов определения состава тела постоянно расширяются.

Различные соотношения показателей состава тела непосредственно связаны с состоянием физической работоспособности спортсменов [5; 6], тесно коррелируют с биохимическими и функциональными показателями организма, широко используемыми в спорте.

Цель работы - исследовать компоненты состава массы тела высококвалифицированных гребцов на каноэ и взаимосвязь данных измерений с результатами выступлений.

Методика и объекты исследования. Были исследованы высококвалифицированные гребцы на каноэ обоего пола, выступающих на различных дистанциях (200, 500, 1000 и 5000 метров). Всего исследовалось 146 спортсменов, из них - 124 мужчины и 22 женщины.

Для определения жировой, мышечной и костной масс использовались формулы Я. Матейки [1921] и Э. Г. Мартиросова (1982). Связь между показателями состава тела и спортивным результатом устанавливали, определив при статистической обработке коэффициент корреляции (r) (Бурякин, 2015).

Взаимосвязь данных измерений с результатами выступлений высококвалифицированных гребцов на каноэ представлена в табл. 1-6.

В таблицах приводятся средние арифметические величины $(\bar{X})$ отобранных характеристик для двух групп высококвалифицированных спортсменов, абсолютные $(\sigma)$ и относительные (V\%) показатели варьирования, а также коэффициенты корреляции со спортивным результатом.

Результаты и их обсуждение. В табл. 1 представлены статистические результаты состава массы тела гребцов на каноэ, специализирующихся на соревновательной дистанции 200 м.

Показатели состава массы тела высококвалифицированных гребцов

Таблииа 1 на каноэ и их взаимосвязь со спортивным результатом (C-1, 200 м, мужчины)

\begin{tabular}{|c|c|c|c|c|c|c|c|c|}
\hline \multirow{4}{*}{ Показатель } & \multicolumn{8}{|c|}{ Квалификация спортсмена } \\
\hline & \multicolumn{4}{|c|}{$\begin{array}{l}\text { 3МС, МСМК } \\
\mathbf{n}=14\end{array}$} & \multicolumn{4}{|c|}{$\underset{\substack{\mathrm{MC}, \mathrm{KMC} \\
\mathrm{n}=22}}{ }$} \\
\hline & \multicolumn{8}{|c|}{ статистические результаты } \\
\hline & $\bar{X}$ & $\sigma$ & $\mathrm{V} \%$ & $\mathbf{r}$ & $\bar{X}$ & $\sigma$ & V\% & $\mathbf{r}$ \\
\hline Жировая масса, \% & $6,40^{*}$ & 2,73 & 5,84 & 0,569 & $11,87 *$ & 1,84 & 5,62 & $-0,487$ \\
\hline Мышечная масса, \% & $57,38^{*}$ & 2,64 & 3,78 & 0,386 & $52,51 *$ & 1,93 & 6,73 & 0,584 \\
\hline Костная масса, \% & 14,62 & 3,06 & 5,72 & 0,578 & 15,74 & 2,84 & 7,19 & $-0,762$ \\
\hline Гребля, 200 м, $c$ & $44,58^{*}$ & 2,68 & 5,91 & - & $48,62 *$ & 3,16 & 5,59 & - \\
\hline
\end{tabular}

Примечание. $t$-критерий Стьюдента, * - $p<0,05$; коэффициенты корреляции достоверны при $r<0,390$ для 5 \% уровня значимости.

Сравнительный анализ состава массы тела между каноистами различной квалификации, специализирующимися в гонках на 200 м (рис. 1), показал, что по показателям жировой, мышечной массы тела и времени прохождения соревновательной 200 -метровой дистанции наибольшие результаты имеют 3МС и МСМК по сравнению с гребцами-каноистами из групп МС и КМС. Различия в среднем составляют, соответственно, 5,47; 4,77 \% и 4,04 с. Данные различия статистически достоверны ( $<0,05)$. Коэффициенты корреляции исследуемых показателей массы тела гребцов на каноэ имеют достаточно прочную связь с результатом прохождения 200-метровой соревновательной дистанции. Однако эта связь статистически не достоверна $(\mathrm{p}>0,05)$.

В табл. 2 представлены статистические результаты показателей состава массы тела женщин, специализирующихся в гребле на каноэ на дистанции 200 м.

При анализе полученных восьми данных выявлено, что группа МСМК и ЗМС имеют лучшие результаты, чем группа МС и КМС, как по времени прохождения 200-метровой дистанции, так и по показателям состава массы тела. Различия при прохождении соревновательной дистанции 200 м составили в среднем 2,99 с. В показателях процентного содержания мышечной массы в группе ЗМС и МСМК и группе МС и КМС различия достоверно значимы ( $<<0,05)$. При этом коэффициенты корреляции показателей массы тела гребцов имеют прочную связь с результатом прохождения 200-метровой дистанции. 


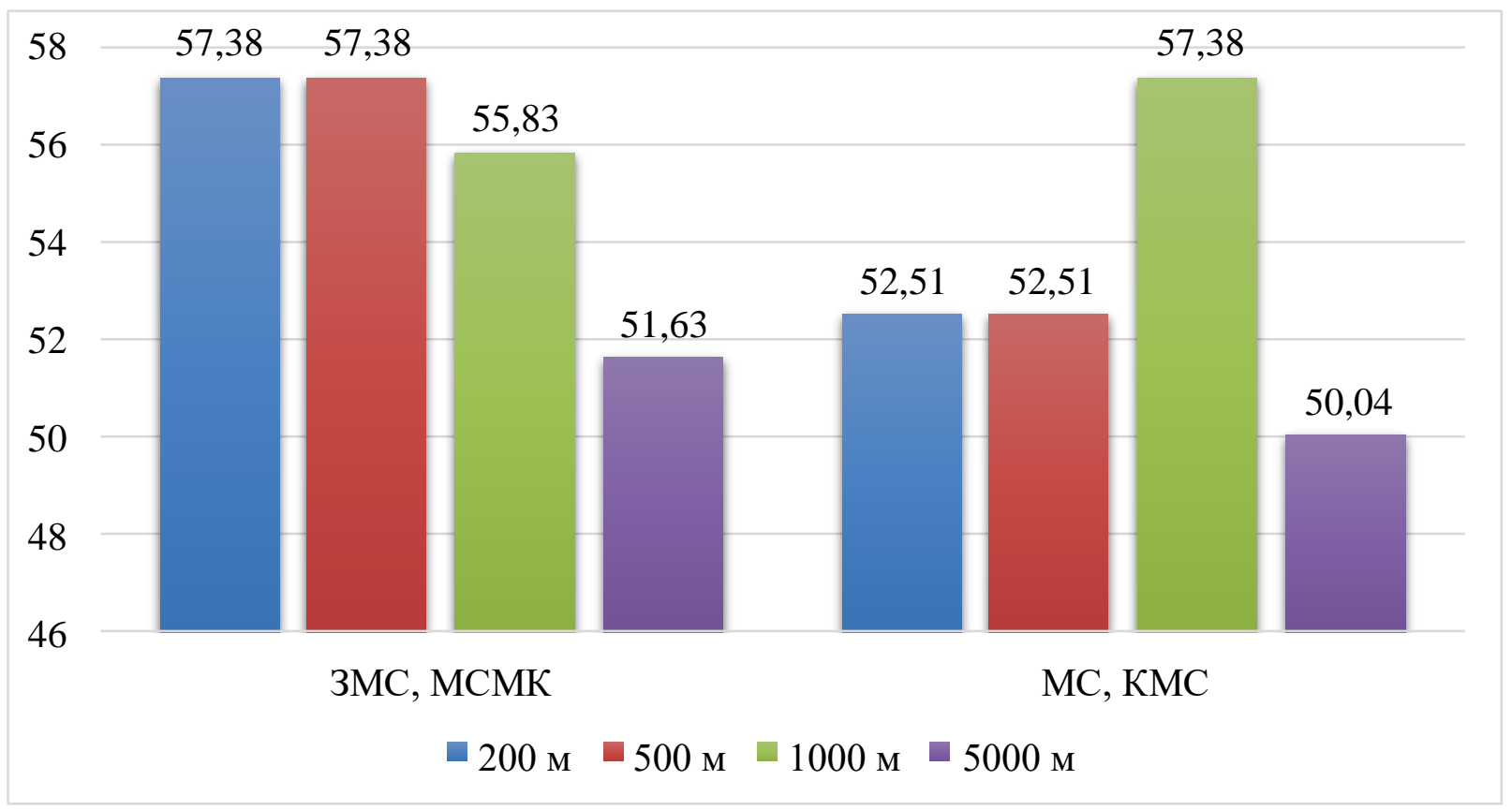

Рис. 1. Относительная мышечная масса (\%) спортсменов различной квалификации, специализирующихся в гребле на каноэ

Таблица 2

Показатели состава массы тела высококвалифицированных гребцов на каноэ и их взаимосвязь со спортивным результатом (C-1, 200 м, женщины)

\begin{tabular}{|c|c|c|c|c|c|c|c|c|}
\hline \multirow{4}{*}{ Показатель } & \multicolumn{8}{|c|}{ Квалификация спортсмена } \\
\hline & \multicolumn{4}{|c|}{$\underset{\mathrm{n}=8}{\text { 3MC, }}$} & \multicolumn{4}{|c|}{$\underset{\mathrm{n}=14}{\mathrm{MC}, \mathrm{KMC}}$} \\
\hline & \multicolumn{8}{|c|}{ статистические результаты } \\
\hline & $\bar{X}$ & $\sigma$ & V\% & $\mathbf{r}$ & $\bar{X}$ & $\sigma$ & $\mathrm{V} \%$ & $\mathbf{r}$ \\
\hline Жировая масса, \% & $7,93^{*}$ & 1,64 & 8,37 & 0,479 & $15,31 *$ & 3,26 & 6,95 & $-0,483$ \\
\hline Мышечная масса, \% & $55,13^{*}$ & 8,49 & 3,42 & 0,584 & $50,43 *$ & 7,83 & 8,63 & 0,629 \\
\hline Костная масса, \% & 13,64 & 2,47 & 6,75 & 0,629 & 14,76 & 3,08 & 6,38 & $-0,338$ \\
\hline Гребля 200 м, $c$ & 49,95 & 2,12 & 5,93 & - & 52,94 & 3,82 & 5,56 & - \\
\hline
\end{tabular}

Примечание. $t$-критерий Стьюдента, * - $p<0,05 ;$ коэффищиенты коррелящии достоверны при r<0,390 для $5 \%$ уровня значимости.

В результате анализа полученных результатов выявлено, что группа МСМК и ЗМС имеет лучшие результаты, чем группа МС и КМС по времени прохождения 200-метровой дистанции, разница которого составила в среднем $2,99 \mathrm{c}$.

Между показателями жировой и мышечной массы в спортсменок обследуемых групп различия составили, соответственно, 7,70 и 7,38 \% (p<0,05). Корреляционная связь исследуемых показателей состава массы тела со спортивным результатом достаточно тесная. Однако лишь в группе МС и КМС между спортивным результатом и костной массой спортсменок, где $\mathrm{r}=-0,338$, взаимосвязь достоверна $(\mathrm{p}<0,05)$.

Сравнительный анализ состава массы тела между каноистами различной квалификации, специализирующимися в гонках на 500 м (табл. 3) выявил, что по показателям жировой, мышечной, костной массы и времени прохождения соревновательной 500-метровой дистанции лучшие результаты имеют ЗМС и МСМК, чем каноисты из группы МС и КМС. Коэффициенты корреляции показателей массы тела гребцов на каноэ имеют достаточно прочную связь с результатом прохождения 200-метровой дистанции. Однако эта связь статистически не достоверна $(\mathrm{p}>0,05)$.

Анализ полученных результатов (табл. 4) показал, что группа МСМК и ЗМС, специализирующаяся в женской гребле на каноэ-двойке на соревновательной дистанции 500 м, имеет лучшие результаты, по сравнению с группой МС и КМС, по времени прохождения данной дистанции, разница которого составила в среднем 2,99 с. 
Показатели состава массы тела высококвалифицированных гребцов на каноэ и их взаимосвязь со спортивным результатом (C-1, 500 м, мужчины)

\begin{tabular}{|c|c|c|c|c|c|c|c|c|}
\hline \multirow{4}{*}{ Показатель } & \multicolumn{8}{|c|}{ Квалификация спортсмена } \\
\hline & \multicolumn{4}{|c|}{$\begin{array}{c}\text { 3МС, МСМК } \\
\text { n=14 }\end{array}$} & \multicolumn{4}{|c|}{$\begin{array}{c}\text { MC, } \mathbf{K M C} \\
n=22\end{array}$} \\
\hline & \multicolumn{8}{|c|}{ статистические результаты } \\
\hline & $\bar{X}$ & $\sigma$ & $\mathrm{V} \%$ & $\mathbf{r}$ & $X$ & $\sigma$ & $\mathrm{V} \%$ & $\mathbf{r}$ \\
\hline Жировая масса, \% & $6,40 *$ & 2,73 & 5,84 & 0,569 & $11,87^{*}$ & 1,84 & 5,62 & $-0,487$ \\
\hline Мышечная масса, \% & $57,38^{*}$ & 2,64 & 3,78 & 0,462 & $52,51 *$ & 1,93 & 6,73 & $-0,647$ \\
\hline Костная масса, \% & 14,62 & 3,06 & 5,72 & 0,369 & 15,74 & 2,84 & 7,19 & $-0,486$ \\
\hline Гребля 500 м, мин. $c$ & $1: 52,61$ & 3,58 & 6,86 & - & $1: 57,36$ & 4,17 & 5,28 & - \\
\hline
\end{tabular}

Примечание. $t$-критерий Стьюдента, * - p<0,05; коэффициенты корреляции достоверны при $r<0,390$ для 5 \% уровня значимости.

Таблица 4

Показатели состава массы тела высококвалифицированных гребцов на каноэ и их взаимосвязь со спортивным результатом (C-2, 500 м, женщины)

\begin{tabular}{|c|c|c|c|c|c|c|c|c|}
\hline \multirow{4}{*}{ Показатель } & \multicolumn{8}{|c|}{ Квалификация спортсмена } \\
\hline & \multicolumn{4}{|c|}{$\begin{array}{l}\text { 3MC, MCMK } \\
\qquad=8\end{array}$} & \multicolumn{4}{|c|}{$\begin{array}{c}\mathrm{MC}, \mathrm{KMC} \\
\mathrm{n}=14\end{array}$} \\
\hline & \multicolumn{8}{|c|}{ статистические результаты } \\
\hline & $\bar{X}$ & $\sigma$ & $\mathrm{V} \%$ & $\mathbf{r}$ & $\bar{X}$ & $\sigma$ & V \% & $\mathbf{r}$ \\
\hline Жировая масса, \% & $7,93 *$ & 3,64 & 8,37 & 0,721 & $15,31 *$ & 3,26 & 6,95 & $-0,483$ \\
\hline Мышечная масса, \% & $55,13 *$ & 3,42 & 6,94 & 0,584 & $50,43 *$ & 2,83 & 8,63 & 0,629 \\
\hline Костная масса, \% & 13,64 & 2,47 & 6,75 & 0,352 & 14,76 & 3,08 & 6,38 & $-0,384$ \\
\hline Гребля 500, мин. $c$ & $2: 02,56$ & 2,10 & 4,72 & - & 2:04,71 & 2,08 & 3,96 & - \\
\hline
\end{tabular}

Примечание. Коэффициенты корреляции достоверны при r<0,390 для 5 \% уровня значимости по t-критерию Стьюдента.

Между показателями жировой и мышечной массы у спортсменок исследуемых групп различия составили, соответственно, 7,70 и 7,38 \% (p<0,05). Корреляционная связь исследуемых показателей состава массы тела со спортивным результатом достаточно тесная. Выявлена достоверная корреляционная связь между спортивным результатом в группах КМС и $\mathrm{MC}$, где r=-0,384 (p<0,05).

Статистические результаты показателей состава массы тела мужчин, специализирующихся в гребле на каноэ на соревновательной дистанции 1000 м, представлены в табл. 5.

Показатели состава массы тела высококвалифицированных гребцов

Таблица 5 на каноэ и их взаимосвязь со спортивным результатом (C-1, 1000 м, мужчины)

\begin{tabular}{|c|c|c|c|c|c|c|c|c|}
\hline \multirow{4}{*}{ Показатель } & \multicolumn{8}{|c|}{ Квалификация спортсмена } \\
\hline & \multicolumn{4}{|c|}{$\begin{array}{l}\text { 3МC, МСMK } \\
n=18 \\
\end{array}$} & \multicolumn{4}{|c|}{$\begin{array}{c}\mathrm{MC}, \mathrm{KMC} \\
\mathrm{n}=26 \\
\end{array}$} \\
\hline & \multicolumn{8}{|c|}{ статистические результаты } \\
\hline & $\bar{X}$ & $\sigma$ & $\mathrm{V} \%$ & $\mathbf{r}$ & $\bar{X}$ & $\sigma$ & $\mathrm{V} \%$ & $\mathbf{r}$ \\
\hline Жировая масса, \% & $6,47^{*}$ & 2,73 & 5,84 & 0,379 & $10,87^{*}$ & 1,84 & 5,62 & $-0,487$ \\
\hline Мышечная масса, \% & 55,83 & 2,83 & 5,82 & 0,462 & 57,38 & 2,64 & 3,78 & $-0,647$ \\
\hline Костная масса, \% & 15,48 & 2,75 & 6,81 & 0,268 & 15,74 & 2,84 & 7,19 & $-0,762$ \\
\hline Гребля 1000 м, мин. $c$ & $3: 52,54$ & 5,3 & 5,07 & - & $3: 57,73$ & 6,28 & 5,94 & - \\
\hline
\end{tabular}

Примечание. Коэффициенты корреляцฺии достоверны при $r<0,390$ для 5 \% уровня значимости по t-критерию Стьюдента. 
При анализе полученных данных выявлено, что группа каноистов МСМК и ЗМС имеет лучшие результаты, чем в группе МС и КМС, как по времени прохождения 1000-метровой дистанции, так и по показателям состава массы тела (рис. 2).

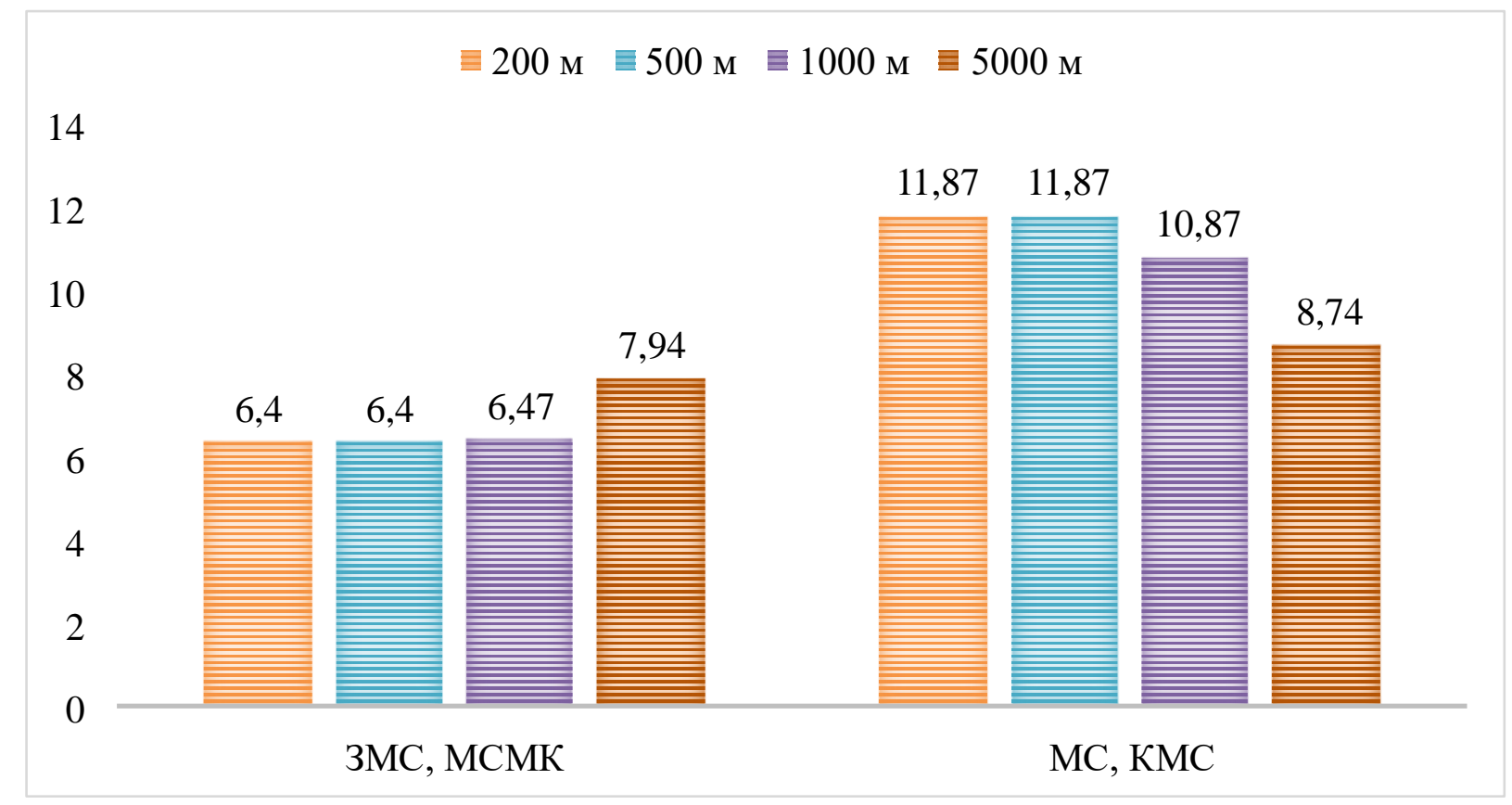

Рис. 2. Относительная жировая масса (\%) спортсменов различной квалификации, специиализирующихся в гребле на каноэ

Различия при прохождении соревновательной дистанции 1000 м составили в среднем 5,19 с. В показателях процентного содержания жировой, мышечной и костной массы тела каноистов обеих групп имелись различия, однако статистически достоверными они не являлись. При этом коэффициенты корреляции показателей массы тела гребцов имеют прочную связь с результатом прохождения 1000-метровой дистанции. А связь показателей жировой массы с временем прохождения соревновательной дистанции статистически достоверна, где коэффициент корреляции составил 0,381, при r $<0,390$ для 5 \% уровня значимости.

В табл. 6 представлены статистические результаты показателей состава массы тела мужчин, специализирующихся в гребле на каноэ на соревновательной дистанции 5000 м.

Таблица 6

Показатели состава массы тела высококвалифицированных гребцов на каноэ и их взаимосвязь со спортивным результатом (C-1, 5000 м, мужчины)

\begin{tabular}{|c|c|c|c|c|c|c|c|c|}
\hline \multirow{4}{*}{ Показатель } & \multicolumn{8}{|c|}{ Квалификация спортсмена } \\
\hline & \multicolumn{4}{|c|}{$\begin{array}{l}\text { 3MC, MCMK } \\
n=18\end{array}$} & \multicolumn{4}{|c|}{$\begin{array}{c}\text { MC, KMC } \\
\text { n=26 }\end{array}$} \\
\hline & \multicolumn{8}{|c|}{ 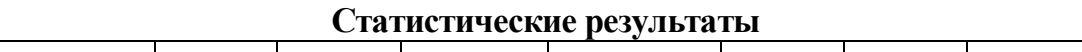 } \\
\hline & $\bar{X}$ & $\sigma$ & V \% & $\mathbf{r}$ & $\bar{X}$ & $\sigma$ & V \% & $\mathbf{r}$ \\
\hline Жировая масса, \% & 7,94 & 2,48 & 4,93 & 0,489 & 8,74 & 2,46 & 4,65 & $-0,462$ \\
\hline Мышечная масса, \% & 51,63 & 2,47 & 3,84 & 0,368 & 50,04 & 2,36 & 5,72 & $-0,371$ \\
\hline Костная масса, \% & 13,84 & 2,46 & 5,68 & 0,624 & 14,08 & 2,13 & 6,02 & $-0,495$ \\
\hline Гребля 5000 м, мин. $c$ & $23: 09,34$ & 3,75 & 5,82 & - & $23: 25,31$ & 4,62 & 3,26 & - \\
\hline
\end{tabular}

Примечание. Коэффициенты корреляции достоверны при $r<0,390$ для 5 \% уровня значимости по $t$-критерию Стьюдента.

При анализе полученных данных выявлено, что группа МСМК и ЗМС имеет лучшие результаты, чем $\mathrm{MC}$ и КМС, как по времени прохождения 5000-метровой дистанции, так и по показателям состава массы тела. Различия при прохождении соревновательной дистанции 5000 м составили в среднем 16,03 с. В показателях процентного содержания жировой, мышечной и костной массы тела байдарочников обеих 
групп имелись различия, однако статистически достоверными они не являлись (р>0,05). Однако выявлена прочная корреляционная связь показателей массы тела каноистов с результатом прохождения 5000-метровой дистанции. При этом взаимосвязь показателей мышечной массы тела спортсменов обеих групп со временем прохождения дистанции статистически достоверна, где коэффициент корреляции составил, соответственно, 0,368 и -0,371 при $\mathrm{r}<0,390$ для $5 \%$ уровня значимости по t-критерию Стьюдента.

Выводы. Выявлено, что группа МСМК и ЗМС у мужчин на дистанции 200 м по жировой и мышечной массе тела превосходят группу МС и КМС. Различия достоверно значимы $(\mathrm{p}<0,05)$. Корреляционная связь показателей состава массы тела гребцов с результатом прохождения дистанции достаточно тесная, однако не достоверна. У женщин по показателям жировой и мышечной массы в группе ЗМС и МСМК и группе МС и КМС различия достоверно значимы $(p<0,05)$. Коэффициент корреляции достоверен в группе МС и КМС между спортивным результатом и костной массой тела.

Отмечается, что на дистанции 500 м лучшими показателями обладают спортсмены группы МСМК и ЗМС как у мужчин, так и у женщин. По показателям жировой и мышечной массы у спортсменок исследуемых групп различия достоверно значимы $(p<0,05)$. Корреляционная связь исследуемых показателей состава массы тела со спортивным результатом достаточно тесная.

На дистанции 1000 м наилучшими значениями обладают спортсмены группы МСМК и ЗМС, но значения статистически не достоверны. Корреляционная связь достоверна по показателю жировой массы со временем прохождения соревновательной дистанции $(\mathrm{p}<0,05)$.

Выявлено, что группа МСМК и ЗМС у мужчин обладает лучшим результатом, чем группа МС и КМС, как по времени прохождения 5000-метровой дистанции, так и по показателям состава массы тела, однако различия не достоверны ( $>0,05)$. Отмечается достоверный коэффициент корреляции по показателям мышечной массы тела спортсменов обеих групп со временем прохождения дистанции.

\section{Источники и литература}

1. Брожек И. Определение компонентов человеческого тела. Вопросы антропологии. 1960. Вып. 5. С. 31-53.

2. Гавриленко М. Н., Алексанян Г. Д. Некоторые морфологические особенности конституционных характеристик высококвалифицированных гребцов на байдарках и каноэ. Фундаментальные исследования/Российская академия естествознания. № 7. 2007. С. 34-41.

3. Давыдов В. Ю. [и др.]. Технология отбора и ориентации гребцов на байдарках и каноэ в системе многолетней подготовки: пособие: в 2 ч. Мозырь: МГПУ им. И. П. Шамякина, 2015. Ч. 1. 320 с.

4. Мартиросов Э. Г. Вопросы антропологии. Спорт в современном обществе: материалы междунар. конгресса. Тбилиси, 1980. 246 с.

5. Мартиросов Э. Г. Методы исследования в спортивной антропологии. Москва: Физкультура и спорт, 1982. $282 \mathrm{c}$.

6. Matiegka J. Antropologie. Praha. Vol.11. № 4. 1925.

\section{References}

1. Brozhek, I. (1960). Opredeleniye komponentov chelovecheskogo tela. Voprosy antropologii, 5, 31-53.

2. Gavrilenko, M. N., Aleksanyan, G. D. (2007). Nekotoryye morfologicheskiye osobennosti konstitutsionnykh kharakteristik vysokokvalifitsirovannykh grebtsov na baydarkakh i kanoe. Fundamentalnyye issledovaniya. Rossiyskaya Akademiya Estestvoznaniya, 7, 34-41.

3. Davydov, V. Yu. (2015). Tekhnologiya otbora i oriyentatsii grebtsov na baydarkakh i kanoe v sisteme mnogoletney podgotovki, Posobiye. Mozyr: MGPU im. I. P. Shamyakina, 320.

4. Martirosov, E. G. (Eds). (1980). Voprosy antropologii. Sport v sovremennom obshchestve, Materialy mezhdunar. kongressa. Tbilisi, 246.

5. Martirosov, E. G. (1982). Metody issledovaniya v sportivnoy antropologii. Moskva: Fizkultura i sport, 282.

6. Matiegka, J. (1925). Antropologie. Praha, 11(4).

Стаття надійшла до редакції 19.04.2019 р. 